\title{
Ecology, management and monitoring of grey dunes in Flanders
}

\author{
Provoost, Sam $^{1 *}$; Ampe, Carole ${ }^{2}$; Bonte, Dries ${ }^{3}$; Cosyns, Eric ${ }^{4,5}$ \& Hoffmann, Maurice ${ }^{1,4}$ \\ ${ }^{1}$ Institute of Nature Conservation, Kliniekstraat 25, B-1070 Brussels, Belgium; ${ }^{2}$ Ghent University, Laboratory of \\ Soil Science, Krijgslaan 281, B-9000 Gent, Belgium; E-mail carole.ampe@rug.ac.be; ${ }^{3}$ Ghent University, \\ Research group terrestrial Ecology, K.L. Ledeganckstraat 35, B-9000 Gent, Belgium; \\ E-mail dries.bonte@rug.ac.be; ${ }^{4}$ Ghent University, Research group terrestrial Ecology, Krijgslaan 281, \\ B-9000 Gent, Belgium; ${ }^{5}$ E-mail eric.cosyns@rug.ac.be; ${ }^{*}$ Corresponding author; E-mail sam.provoost@instnat.be
}

\begin{abstract}
Grey dunes are a priority habitat type of the European Union Habitats Directive and demand special attention for conservation and management. Knowledge of the ecology of coastal grey dunes can contribute to this policy. Dune grassland succession is initiated by fixation and driven by the complex of soil formation (humus accumulation) and vegetation development. Leaching and mobilization of $\mathrm{CaCO}_{3}$, which are important in nutrient dynamics, complicate the picture. At present, grass- and scrub encroachment greatly overrules these fine scaled soil processes and causes substantial loss of regional biodiversity. Belgium has an international responsibility in grey dune conservation because of the limited range of its characteristic vegetation, flora and fauna. As biomass removal seems essential in grassland preservation, grazing is an important management tool. Evaluation of management measures focuses on biodiversity measurements on the levels of landscape, community and species.
\end{abstract}

Keywords: Ammophila arenaria; Belgian coast; Biodiversity; Decalcification; Dune fixation: Habitats Directive.

\section{Introduction}

Grey dunes, defined as 'fixed coastal dunes with herbaceous vegetation' in the CORINE biotope classification, are considered a priority in the Annex I of the EU Habitats Directive. This status implies that grey dunes deserve special conservation attention. Therefore it is useful to focus on the ecology of this landscape and its vegetation and to discuss the contribution of ecological research to conservation strategy, management and monitoring. This paper summarizes the experience in Belgian coastal dunes, based on several research projects. This research is to a large extent funded by the Nature division of the Ministry of the Flemish Community, with contributions of LIFE.

Coastal grey dune is most readily defined using plant communities. Phytosociologically, grey dune vegetation includes moss dunes and dune grasslands (with a distinct A horizon), belonging to the Cladonio-Koelerietalia.

In landscape-ecological terms grey dunes can be considered as the dry component of the 'stressed dune landscape' (Provoost 2004). In such a landscape, biological dynamics show a certain equilibrium between 'top down' regulating stress factors and 'bottom up' community succession. Dominance of top down regulation, for instance by blowing sand, would lead towards a 'dynamic landscape' - in casu marram dunes with Marram grass, Ammophila arenaria, mixing with the moss- and lichen-dominated Cladonio-Koelerietalia vegetation, while dominance of bottom up organization would lead to the development of scrub and woodland with species such as Hippophae rhamnoides and Ligustrum vulgare.

The main differentiating processes are related to dune fixation, soil formation, vegetation development and management. 


\section{Processes in grey dunes}

\section{Dune fixation and erosion}

Dune fixation implies a decrease in aeolian activity and stabilization by vegetation (Jungerius 1990). Rhizome forming plants such as Ammophila arenaria and Festuca juncifolia, which keep up with a certain sand accumulation, play an important part and decaying tussocks of Ammophila arenaria become a substantial source of nitrogen in the early stages of grey dune development.

In Europe, mobility of dunes is generally affected by coastal defence works (stabilization) and human activities leading to erosion. Centuries of agricultural use of dunes have probably caused a great deal of secondary sand drift and as these activities ceased somewhere during the 20th century, the dune landscape became fixed and vegetated. Other elements, such as the military activities during World War I, have been quite devastating in a much shorter time span. More recently, intensive recreation causes soil and vegetation degradation, often resulting in local dune mobilization.

\section{Humus accumulation and decomposition}

The initial dune substrate is not very hospitable for plant growth. Parent material of Belgian dune soils consists of well drained sand (mean median grain size between 175 and $250 \mu \mathrm{m}$ ) with a low nutrient content. Drought stress is caused by climatological, geomorphological and soil factors. Grey dune surface exposed to the sun can heat up to more than $60^{\circ} \mathrm{C}$ (Fig. 1) and soils can dry out down to $20 \mathrm{~cm}$ deep (Aggenbach \& Jalink 1999). Especially in moss-covered dunes, the

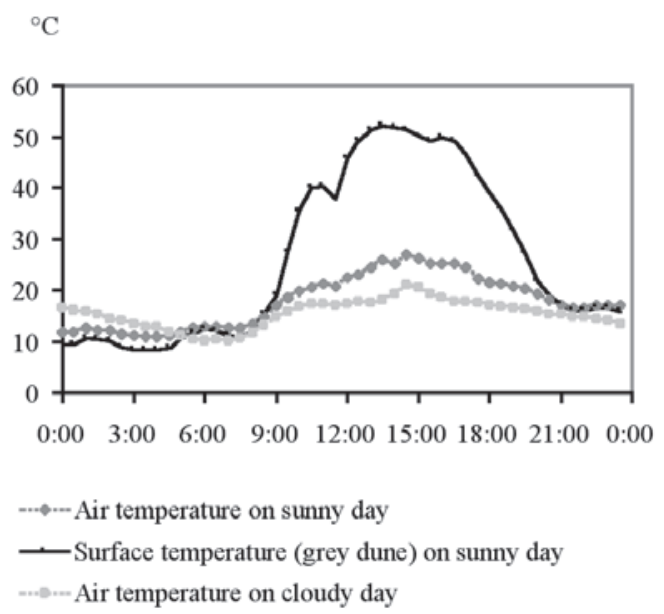

Fig. 1. Air and soil surface temperature on a sunny and cloudy day (17 August and 30 August 2001, respectively) on a southfacing dune slope in De Westhoek, De Panne, Belgium. additional effect of water repellence, caused by soil organic matter, is an underestimated factor of drought. This drought stress regime can strongly retard vegetation succession and soil development.

Despite these very harsh conditions, even in the early moss dune stages some biomass production can take place. It is the key element in soil development. Humus colloids, produced by decomposition of organic matter, increase moisture retention and nutrient availability. Accumulation of humus is reflected in species composition and species' competitive abilities; in Belgian dunes, plant species such as Sagina nodosa and Linum catharticum occur beyond the reach of groundwater only if soils are rich in organic matter. Since soil and vegetation processes are highly interwoven, early stages of dune grassland development represent a classic example of internal succession according to the resource-ratio model of Tilman (1985). Many of the processes take place in the rhizosphere and are driven by competition for water and nutrients. According to Slings (1994), grass roots are the main source of organic matter in grey dune soils. Veer \& Kooijman (1997) found that root and moss biomass each are twice as large as above ground vascular plant biomass, so probably mosses play an important role as well.

Soil humidity is a main determining factor in biomass production and soil development. The effect of the groundwater level on soil organic matter in Belgian coastal dunes is illustrated in Fig. 2. Data are derived from 267 soil samples in the western part of the Belgian coast (Provoost \& Ampe unpubl.; Waumans 2001). Organic matter was determined with loss on ignition $\left(500{ }^{\circ} \mathrm{C}\right.$ during $\left.8 \mathrm{hr}\right)$ and groundwater levels are interpolated from nearby surrounding piezometers. Taking into account annual groundwater fluctuations of 0,5 to $1 \mathrm{~m}$, the capillary effect and rooting depth, groundwater exceeding a depth of about $2 \mathrm{~m}$ under the soil surface is no longer accessible for most grassland plants. In this dry zone, soil organic matter contents rarely exceeds about



Fig. 2. Soil organic matter content (loss on ignition) in the Ahorizon in relation to groundwater level (see Text). 
$6 \%$. In moist dune grasslands, where the groundwater table does not drop below $2 \mathrm{~m}$ but soils never get inundated, maximum organic matter contents of 10 to $15 \%$ are observed. These figures are comparable to the situation in dunes on Goeree in the southwestern Netherlands (Annema \& Jansen 1998). Wet soils are permanently influenced by groundwater and show a spectacular increase in (maximum) soil organic matter content.

Humus accumulation is counteracted by several processes. In young moss dunes, physical humus erosion can be substantial, but in stable grassland, main losses of soil organic matter are due to biochemical decomposition. The ions formed by mineralization processes and $\mathrm{CaCO}_{3}$ are susceptible to leaching, caused by the precipitation surplus. Bioturbation enforces decomposition and mineralization. According to Bonte et al. (2003), ants affect the thickness of the A-horizon and the soil penetration resistance (Fig. 3). These animals as well as snails and other animals, are abundant in organic soil layers.

In general, decomposition rates show an optimumtype response in relation to soil moisture. Within the humidity range of dune grassland, the net effect of biomass production and mineralization leads to the pattern in soil organic matter contents shown in Fig. 2.

\section{Soil decalcification and nutrient dynamics}

Stabilized dune soils decalcify due to continuous carbonate leaching. At the time of deposition, the sand is calcareous (up to $8 \% \mathrm{CaCO}_{3}$ ) due to shell fragments (Depuydt 1972). $\mathrm{CaCO}_{3}$ is the main buffering substance and $\mathrm{pH}$ remains neutral to alkaline (6,5 up to 8$)$ as long as $\mathrm{CaCO}_{3}$ concentration exceeds about $0,3 \%$. But below this point soil acidity shows an abrupt and steep decline, which means that the gradual character of decarbonatation is not reflected in soil pH (Rozema et al. 1985; Aggenbach \& Jalink 1999).

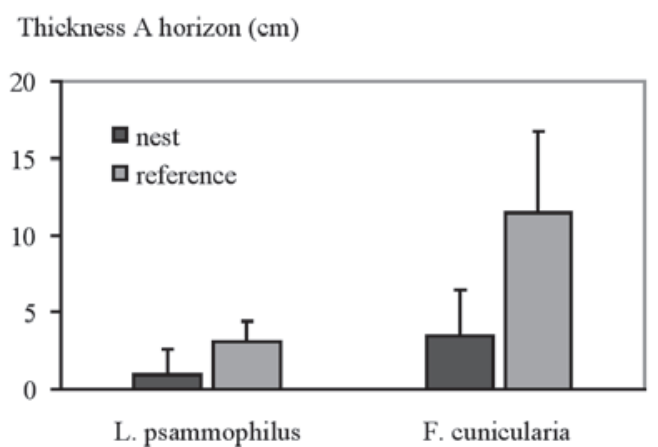

Fig. 3. Effects of the presence of nests of the ants Lasius psammophilus and Formica cunicularia on the thickness of the A-horizon (Bonte et al. 2003).
Acidity is an important parameter, affecting many soil processes. Decomposition and mineralization of organic matter is slowed down in acid soils $(\mathrm{pH}<4,5$ to 5 ), resulting in an increase in the humus content (Aggenbach \& Jalink 1999). During soil development, humic acids are released which enforce leaching of $\mathrm{CaCO}_{3}$. This means that humus production and decarbonatation are involved in a positive feedback loop.

Decarbonatation of grey dune soils is slowed down by mobilization of calcareous sand. Bioturbation is probably an essential element. Ants (e.g. Formica cunicularia) certainly increase the superficial lime content (Bonte et al. 2003). Coprogenic fauna, becoming more abundant after the introduction of large herbivores in the grey dunes, bring calcareous sand towards the surface when constructing their brood chambers (Ampe et al. 2002). Weeda (1992) also considers 'sand spray', a slight sand accretion, as an important and characteristic natural cause of recalcification. According to this author, this process prevents soil acidification and enhances decomposition and mineralization of organic material in Taraxaco-Galietum dune grasslands.

Nitrogen and phosphorus are key elements and partly co-limiting in the nutrient dynamics of grey dunes (Kooijman et al. 1998). Nitrogen is mainly supplied by decomposition of plant residues. The total nitrogen content is highly correlated with soil organic matter and generally increases during succession. Mineralization in plant-available nitrogen shows a different response and is rather correlated with standing crop biomass and plant litter quality. Phosphorus availability is $\mathrm{pH}$ dependent and shows an optimum at $\mathrm{pH} 5.2$ in calcareous dunes in The Netherlands (Kooijman \& Besse 2002). At higher $\mathrm{pH}$, phosphorus is largely fixed in calcium phosphate, limiting biomass production. Physiological adaptations to this phosphorus limitation are characteristic of calciphilous plant species.

\section{Vegetation development}

In natural dune systems, fine-scaled soil processes as mentioned above, physical destruction by blowing sand and invertebrate herbivory might be sufficient to preserve grey dune vegetation and some its characteristic species, at least within an ephemeral pattern. But at present, substantial removal of plant biomass seems essential for sustainable dune grassland development. Coastal dune vegetation in Belgium and many other European countries evolves unidirectionally towards coarse grassland with Calamagrostis epigejos, Avenula pubescens or Arrhenatherum elatius, scrub with Hippophae rhamnoides, Ligustrum vulgare or Salix repens 
and woodland (van Til et al. 2002; Provoost \& Van Landuyt 2001). Grass encroachment is probably stimulated by atmospheric deposition but once established, grass-dominated vegetation is highly self-maintaining due to increased nitrogen mineralization (Kooijman et al. 1998; Veer \& Kooijman 1997). Scrub expansion is mainly caused by drastic changes in land use. Up to the middle of the 20th century, livestock grazing was common in Belgian dunes and shrubs and trees were harvested for fuel. Because of these activities the grey dune area covered an unnaturally large portion of the coastal dunes.

Grazing and mowing can maintain vegetation structure but do not stop succession (De Raeve 1989). Soil and vegetation development continues through a different pathway, subject to new processes such as biomass removal, trampling and dung deposition. The natural processes described above can lead to a moder humus form, whereas in situations with livestock grazing a mullmoder develops (Slings 1994; Aggenbach \& Jalink 1999). Such differences can be critical for the occurrence of (plant) species, which is shown for Viola rupestris in The Netherlands by Weeda (1992).

\section{Spatial patterns in grey dunes}

\section{Regional and landscape level}

Biogeographical patterns are related to climate, soil and history. Atlantic grey dunes are subject to a major gradient in temperature from southwest up to northeast and a substantial variety in precipitation (Dahl 1998). Coastal dunes of Belgium and the adjacent areas take an intermediate position with a mean temperature of the coldest month of $2^{\circ} \mathrm{C}$ and an annual precipitation of ca. $750 \mathrm{~mm}$. During the months May till August a deficit occurs of ca. $100 \mathrm{~mm}$. Considering the importance of drought stress on grey dunes, climate is determinative for grey dune development and different vegetation types can be distinguished according to the geographical position (Weeda \& Schaminée 1990). Invertebrate communities from North-Atlantic grey dunes respond to these climatological differences as well and are clearly reflected in the declining presence of Mediterranean species at higher latitudes.

Species pools are also affected by their geographical position. North of Belgium, sand deposits and dunes along the rivers Rhine and Meuse act as an ecological corridor between the coast and inland habitats for species such as Euphorbia cyparissias and Eryngium campestre (Doing 1993). But Belgian dunes are more clearly influenced from the south, by the chalk-grasslands in northern France. Most probably, they enriched the dune flora with species such as Asperula cynanchica, Helianthemum nummularium and Thesium humifusum. Salisbury (1952) described the same phenomenon of 'species supply' of British dunes from the downs. Differentiation in invertebrate communities is detected in the function of the surrounding landscape: if woodland, heathland or chalk grassland is present in the proximity, typical species from these habitats also colonize grey dunes, probably within a source-sink context.

On a landscape level, distribution of grey dunes is limited to dry or moderately moist zones within fixed dunes. As most of the dune ridges along the Belgian coast were still mobile some decades ago, only young moss dunes are found in these zones (apart from scrub). Fixed dune grassland with a distinct soil profile is limited to intermediate elevations within large dune slacks or to relief-poor inner dunes. Also patterns in soil acidity are largely revealed on a landscape level. Certainly within a particular moisture range, $\mathrm{pH}$ is mainly influenced by decalcification, which in its turn is mainly time dependent. Thus general grey dune types appearing in a dune area relate to the landscape's ontogeny.

Stress factors form another element in grey dune distribution. The 'sand spray' effect for example, will only take place in the vicinity of mobile dunes. Herbivory pressure can be linked to rabbit density and present-day or historical livestock grazing. In Dutch dunes, an effect of past agricultural activities related to sea villages is reflected in vegetation and species composition (Slings 1994) but this is not distinct along the Belgian coast. Finally, fragmentation of grey dunes due to scrub stands decreases the number of typical invertebrate species within each isolated patch (Bonte et al.2002) because of smaller surfaces and metapopulation dynamics, where colonization and extinction depend on connectivity.

\section{Local level}

Grey dune landscapes are usually characterized by an explicit microrelief, causing a fine-scale variability in microclimate and edaphic factors. These elements primarily determine species composition and performance. Superimposed, plant population dynamics, vegetation architecture and biotic interactions contribute to the development of complex vegetation patterns. As many biological processes such as seed dispersal or herbivory are highly stochastic, prediction of species occurrence becomes precarious (see e.g. Lichter 2000 for a dune example).

The response of several plant species to soil properties suggests that species assemblages change in function of development time, which underlines the importance of the complex processes of plant growth, biotic interactions and soil formation. Terrestrial springtails 
respond positively to this soil characteristic as well. Spiders, which are their predators, aggregate in a similar pattern, not because of direct responses but indirectly by co-evolution for similar microhabitats.

In general, insect and spider communities largely depend on vegetation structure and assemblage stability is strongly influenced by the landscape patterns. Small patches are subject to significant edge effects, resulting in a high number of atypical species and a high spatial community instability (Bonte et al. 2002). Communities in large patches are more stable due to higher internal microhabitat variation and the possibility of attaining viable population sizes. Biotic interaction also explains certain patterns in species composition: a number of invertebrates (monophagous beetles, bugs and butterflies) are bound to typical host plants, while other invertebrates are bound to typical invertebrate hosts. Ants are peculiar in this respect since they host very rare myrmecophilous spiders, bugs, woodlice and probably many more invertebrate taxa.

In the other direction, invertebrates can also influence the presence of plant species. Ants again are of major importance since their nests create suitable germination conditions for several plant species (e.g. Thymus pulegioides). Additionally, they transport seeds to these nests.

\section{Classification of grey dune vegetation}

Phytosociological vegetation research contributed substantially to the present knowledge of dune grasslands (e.g. Rodwell 2000). According to Weeda et al. (1996), the vegetation of most of the Belgian grey dunes belongs to the phytosociological order Cladonio-Koelerietalia, an order of calcicole dune vegetation within the class Koelerio-Corynephoretea. Within the order two alliances are distinguished: the Tortulo-Koelerion, including pioneer grasslands and moss-covered dunes and the PolygaloKoelerion containing closed grasslands on soils with a distinct organic layer. Within these alliances several associations have been distinguished. Their composition of which depends largely on local circumstances; each segment of the European coast is after all characterized by a unique combination of climate, geomorphology, soil (e.g. reflected in $\mathrm{CaCO}_{3}$ content) and history. Belgian dune grasslands were described phytosociologically by Heinemann (in Lebrun 1949) as Anthyllido-Thesietum.

Phytosociological classification, with an emphasis on species composition, is quite abstract and often field situations are hard to fit into the scheme because they are degraded, in a subdeveloped stage, or are intermediate between 'pure' associations. The presence of one species, for example Rosa pimpinellifolia, will hardly affect the position in a vegetation classification but might be of major importance for an invertebrate's habitat. A local typology for management planning or evaluation or other ecological applications can be more useful if physiognomic properties and species dominance is emphasized. Also, the use of fuzzy classification techniques, with gradual transitions between distinct types, might be helpfuk.

\section{Nature conservation and management}

\section{Why preserve grey dunes?}

In conservation policy, biodiversity - or rather the loss of it - is generally used as a framework for nature evaluation (Reid \& Miller 1989). In the ecosystem vision on coastal dunes of the Flemish government, this is translated as "conservation or development of the characteristic habitat diversity by as natural as possible means' (Provoost \& Hoffmann 1996).

In an international context, the importance of grey dunes is reflected in the designation as a priority habitat in the EU Habitats Directive, mainly because of its limited range. The Cladonio-Koelerietalia are considered a northern Atlantic vegetation type (Weeda \& Schaminée 1990). Most of the characteristic grey dune plant species appearing in Belgium however, are not threatened, at least not in a European context. None of its characteristic species is included in the Bern Convention list. A number of species, such as Erodium lebelii (= E.glutinosum), and probably some infraspecific maritime varieties of Ononis repens, Koeleria albescens and others, are limited to Atlantic grey dunes (Doing 1993; Roisin 1969). This underlines the habitat specificity and the international responsibility for conservation. Asparagus prostratus is probably the best 'flagship' species for Flanders, since it is strictly Atlantic and, at least regionally, rare and limited to grey dunes. Recent research has confirmed its status as a separate species, distinct from A. officinalis (Kay et al. 2001).

Within the Flemish region, grey dunes are important for conservation of Red List species, including regionally rare chalk grassland species, e.g. Thesium humifusum, Cirsium acaule and Asperula cynanchica, or species characteristic of grasslands of dry to moist nutrient-poor soils.

From an invertebrate fauna perspective, grey dunes are the most endangered dune habitat, certainly within a Flemish context. Most characteristic dune invertebrates however, are found in more dynamic habitats such as mobile dunes and young dune slacks. 


\section{Threats and management}

Along the western part of the Belgian coast, the grey dune area decreased from 730 to 350 ha since the 1950s, mainly due to urbanization and scrub encroachment. In addition, grey dunes are subject to internal degradation due to the grass encroachment mentioned above. Until now, this evolution was not accompanied by a drastic decline in the total number of grey dune species. However, there is an apparent qualitative shift toward a less specific flora, which includes garden escapes and exotic species (Provoost \& Van Landuyt 2001).

This biodiversity decline, at least regionally, urges managers to take nature management measures. Removal of scrub and woodland, mowing and grazing, have proven to be appropriate tools for dune grassland restoration. Well documented examples of management schemes are available for the Dutch dunes (e.g. Annema \& Jansen 1998) and the LIFE initiative at the Sefton coast in the UK (Houston et al. 2001). In Belgian dunes, around 15 ha of scrub has been removed and currently nearly 350 ha are grazed (Herrier \& Killemaes 1998). Mowing is only very locally used for grey dune management.

\section{Preliminary evaluation of grazing}

Expectations of grazing as a management tool are often ample. Herbivores should maintain the open areas after mechanical shrub removal and prevent scrub encroachment. They are expected to preserve biodiversity and to transform species-poor vegetation into species rich grasslands.

Vegetation composition responds to grazing in a rather slow manner - over decades rather than years. In order to evaluate short-term effects, the feeding ecology of introduced ungulates (Konik and Shetland pony, donkey and Scottish Highland cattle) is studied in several dune areas along the Belgian coast. Diet, habitat use and behaviour are registered through all seasons and day periods. The first results show that all domestic herbivores are mainly grass eaters ( 70 to $80 \%$ of their diet is composed of grasses and sedges) and they prefer grassland to graze in (Hoffmann et al. 2001; Cosyns et al. 2001). Diet composition is affected by seasonality: during winter and early spring especially cattle and donkey consume a significant amount of browse (Ligustrum vulgare or Salix repens). Nonetheless browsing intensity is not sufficient to push back or to prevent scrub encroachment (van Breukelen et al. 2002). Hippophae rhamnoides, the most prominent shrub species, is hardly eaten by the herbivores. The animals do seem to respond to the spontaneous vegetation developments.

Rough vegetation, dominated by Calamagrostis epigejos, which succeeds in patches of decayed scrub, is successfully tackled and the impact of grazing on these and other species-poor grasslands can be significant. In most cases biomass of the dominant grass species collapses and after 3-4 yr several stress-tolerant dune grassland species occur.

However, grazing does not simply influence scrub dynamics but it also affects shrub seed germination and development via soil and vegetation structure. Probably vegetation dynamics under grazing management fits in a shifting mosaic pattern similar to the grazed woodlands as described by Olff et al. (1999).

Recruitment of favourable plant species seems to be promoted not only by grazing activity itself but also by trampling, scratching or dust bathing (creating favourable germination micro sites) and defecation. The latter shows the potential to bring in significant amounts of viable seeds of several plant species, including some of conservation interest (Cosyns et al. subm.). Invertebrates react even faster on changes in the vegetation and landscape structure.

Soil nutrients are redistributed through excretion. Most long-term observations show a decrease in $\mathrm{C} / \mathrm{N}$ ratio. Simultaneously a large range of dung fauna appears in the soil system, increasing bioturbation and enlarging the soil volume suitable for rooting.

\section{Monitoring}

\section{Which kind of monitoring?}

Dune management surpassed the experimental, small-scale stage, also in Belgium. One of the future challenges will be to elaborate sustainable and efficient management programmes, with efficiency being measured mainly in terms of biodiversity gain related to cost. This will require more detailed measurements in monitoring and continuous feedback to management planning (Fig. 4).

In a strict sense, monitoring implies repeated survey and an assessment to what degree the results deviate from a predetermined norm (Goldsmith 1991). In practice however, a lot of 'monitoring' does not meet this definition. The surveillance of the environmental context (climate, geomorphology and hydrology) for instance is meant as a multi-purpose frame of reference which must enable us to estimate the relative importance of general (natural) and local, management driven change.

Firstly, direct information can be gathered for many taxonomic groups using various sampling techniques. However, there is a strong trade-off between detail and geographical range. If the inventory effort seems to 
large, indirect biodiversity measurement using habitat models is more appropriate. This requires the selection of a set of habitat parameters of a certain species or species group, which are easily mapped on a large surface. And of course, before all, the species' habitat characteristics must be thoroughly understood.

\section{Landscape level}

Detailed information about topography, preferably in combination with hydrology, is of vital importance in dune research. In a GIS environment, abiotic habitat characteristics, such as surface slope and exposition, can easily be derived from a digital elevation model.

Vegetation structure is a basic biotic layer to be added. Vegetation mapping using remotely sensed images is a promising and powerful tool for planning and evaluation of management in spatially heterogeneous environments such as coastal dunes. Most remote sensing techniques are based on detection of reflected solar radiation. Interaction with earth surface features alters the characteristics of the electromagnetic waves, bringing about a 'spectral signature' (Lillesand \& Kiefer 2000). Sand, for example, reflects most radiation, while green plants absorb red light (wave length $0.6-0.7 \mu \mathrm{m}$ ) for photosynthesis and reflect near-infrared (NIR; 0.7 $2 \mu \mathrm{m}$ ) due to properties related to plant tissue structure. These characteristics allow us to estimate the amount of vegetation biomass using detected reflectance differences in red and NIR bands. It is the basic idea of vegetation indices. Many ecological applications in remote sensing are based on multispectral images, consisting of several information bands. False colour photos for instance, with near infrared, red and green bands are very useful for vegetation mapping. Hyperspectral imagery, consisting of up to hundreds of narrow bands, offers very promising possibilities for more detailed

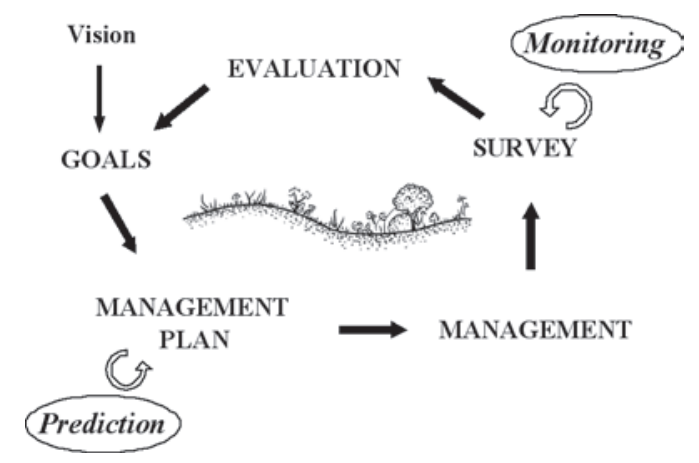

Fig. 4. Cyclic process of planning, management and monitoring in nature conservation. vegetation monitoring but research is still in a early stage.

Detailed nature management evaluation requires high spatial resolutions. At present, satellite sensors offer a 4 $\mathrm{m}$ resolution multispectrally. Even higher resolutions (order of magnitude of $\mathrm{dm}$ ) can only be achieved with digitized aerial photographs or airborne scanners. For management evaluation in some Belgian coastal dunes, digital false colour orthophotos will be used with a spatial resolution of $15 \mathrm{~cm}$. The spectral discernibility of several grey dune vegetation types on these images is illustrated in Fig. 5. Vegetation data are derived from 270 precisely located $1-\mathrm{m}^{2}$ plots in the Oostvoorduinen (Koksijde). Using this information, highly detailed vegetation structure maps can be produced (Droesen 1998) which can be used in habitat models or for evaluation of, for instance, effects of grazing on grass encroachment. In digital grid files, a fuzzy information system can be used, in which affinities for several vegetation types can be assigned to each pixel.

\section{Community level}

Evaluation of species composition requires a detailed survey for which a variety of sampling techniques is at our disposal. Plant communities can be mapped in classical vegetation maps, but these only contain general features. Plot measurements are considered on two levels. Typically, plots with a surface of at most several $\mathrm{m}^{2}$ are used for vegetation research. They can represent homo-

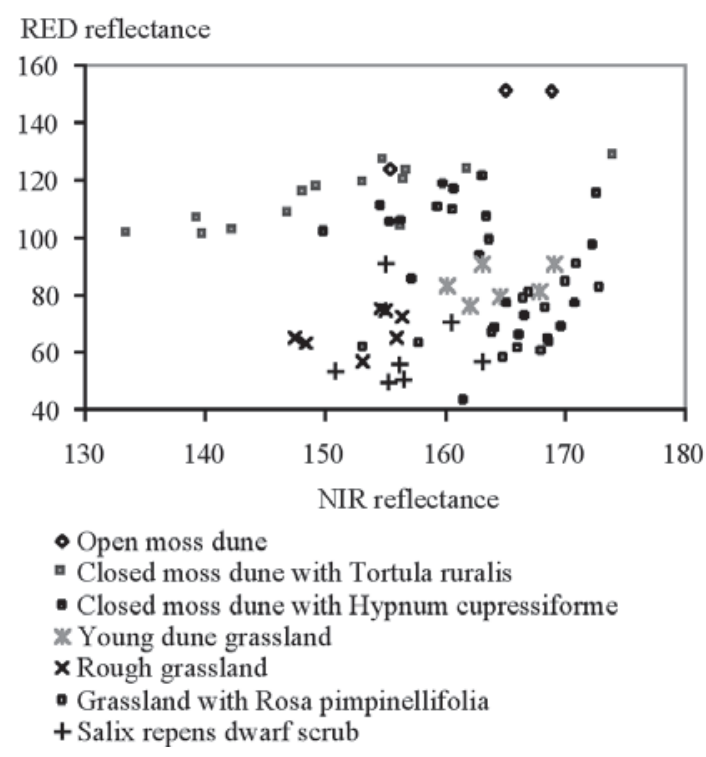

Fig. 5. Spectral signatures of several grey dune vegetation types in red and near infrared bands, based on scanned false colour orthophotos of the Oostvoorduinen, Koksijde. Reflectances are represented as 8 bit digital numbers. 
geneous patches and are necessary to reveal detailed information on vegetation patterns and processes (Bakker et al. 1996). A stratified random set of some 100 permanent quadrats of $9 \mathrm{~m}^{2}$ for example, is used for monitoring the effects of different management regimes at Belgian coastal dunes (Bonte et al. 1998).

However, for management evaluation on the site level, using these small permanent quadrats would imply a very large number of samples to be representative of the whole area. Larger plots, up to several hundreds of $\mathrm{m}^{2}(20 \times 20,50 \times 50)$ could be more appropriate. An approximately equal time investment will provide information on a much larger number of species, although subtle changes in abundance will no longer be detectable. The results will enable a broader quantitative evaluation, which has the extra advantage of being less susceptible to annual fluctuations caused by weather conditions. Plots will be spatially heterogeneous but this should not be considered a disadvantage, since we aim at conclusions at a higher resolution level than the local plant community. Changes can be measured using scores for several habitat types, based on species specificity and abundance.

Standardized pitfall trapping is an effective method for monitoring changes in faunal (invertebrate) composition.

\section{Species level}

Due to sampling, the collected data for rare species will usually not include a sufficient number of replicas for statistical analysis. But just these peculiarities and Red list species are of great interest to the conservationist. Especially for perennial vascular plants, detailed and site-covering inventories of a selection of 'target species' should therefore be considered. If possible, individuals are mapped, otherwise the abundance is estimated within a patch. This method largely excludes statistical problems since the entire population is considered. The occurrence of mobile animals, annual plants and fungi is ephemeral and requires repeated extensive inventories. An example of integral plant inventories in grey dunes is given by Annema \& Jansen (1998) for the dunes of Goeree, The Netherlands. A program is set up for the Flemish coast, based on experience in the western region 'Westkust' (ca. 2000 ha). Grey dune plant species included in this inventory are characteristic of moss dunes (e.g. Viola curtisii or Asparagus prostratus), chalk grasslands (Helianthemum nummularium, Silene nutans or Thesium humifusum) or other grassland types (Rhinanthus minor, Thymus pulegioides or Briza media). A program for detailed mapping of animal populations is worked out on the individual (territorial) level for birds (Oenanthe oenanthe, Saxicola torquata or Galli- ruda cristata) or on the level of the patch occupancy for typical and easily observable invertebrates such as Hipparchia semele, Oedipoda caerulescens, wolfspiders and the Sphecid Bembix rostrata. A follow-up of colonization and extinction dynamics in particular, can reveal interesting data for species conservation.

\section{Conclusions}

An entwined complex of vegetation and soil development is the driving force in grey dune succession. In natural situations, fine scaled dynamics of sand, $\mathrm{CaCO}_{3}$ and nutrients are probably sufficient to maintain low grey dune vegetation, at least locally. At present however, grey dunes spontaneously evolve towards scrub and vegetation dominated by coarse grasses. Biomass removal, e.g. by grazing is essential for preservation of dune grassland but significantly alters the natural system's characteristics. The response of several plants and Collembola to soil organic matter suggests the importance of biological development processes beside or on top of the underlying abiotic pattern. It forms a challenging area for future research.

Atlantic grey dune conservation is of international importance due to the limited range of the characteristic flora and vegetation. Syntaxonomical classification is a valuable tool in conservation but shows some major limitations for vegetation mapping. Incorporation of vegetation structure and physiognomy is important. Fuzzy classification techniques are promising, also in respect to vegetation maps derived from remotely sensed images.

Biodiversity monitoring requires surveys on different scale levels. A combination of detailed vegetation structure maps and inventory of a selection of characteristic and indicative species is a powerful tool for management evaluation. Distinguishing management effects from other changing parameters (natural as well as anthropogenic) remains a difficult but essential task in evaluation.

Grazing management has, at least on short notice, a strong impact on vegetation structure, composition and dynamics and indirectly on faunal elements as well. Its effects on the natural grey dune determinants, such as soil development, are complex and form the subject of further research. 


\section{References}

Aggenbach, C.J.S. \& Jalink, M.H. 1999. Indicatoren voor verdroging, verzuring en eutrofiëring in droge duinen. Staatsbosbeheer, Driebergen, NL.

Ampe, C., Ngugi, N.M. \& Langohr, R. 2002. Impact of recently introduced large herbivores on soil properties of coastal dune soils of the 'Westhoek' nature reserve, Belgium. In: Veloso-Gomes, F., Taveira-Pinto, F. \& das Neves, L. (eds.) The changing coast. Proceedings of the 6th international symposium Littoral 2002, Porto, 22-26 September 2002, Vol III, pp. 433-438. Porto, PT.

Annema, M. \& Janssens, A.E.M. 1998. Het herstel van het vroongrondgebied Midden- en Oostduinen op Goeree. Stratiotes 17: 20-60.

Bakker, J., Olff, H., Willems, J. \& Zobel, M. 1996. Why do we need permanent plots of long-term vegetation dynamics? J. Veg. Sci. 7: 147-156.

Bonte, D., Ampe, C., Hoffmann, M., Langohr, R., Provoost, S. \& Herrier, J.-L. 1998. Monitoring research in the Flemish dunes: from a descriptive to an integrated approach. Proceedings European seminar on coastal dunes, management, protection and research. Skagen, pp. 39-79. Skagen, DK.

Bonte, D., Maelfait, J.-P. \& Baert, L. 2002. Spider assemblage structure and stability in a heterogeneous coastal dune system (Belgium). J. Arachnol. 30: 331-343.

Bonte, D., Dekoninck, W., Provoost, S., Cosyns, E. \& Hoffmann, M. 2003. Microgeographical distribution of ants (Hymenoptera: Formicidae) in a dune grassland and their relation to the soil structure and vegetation. Anim. Biol. 53: 367-377.

Cosyns, E., Degezelle, T., Demeulenaere, E. \& Hoffmann, M. 2001. Feeding ecology of Konik horses and donkeys in Belgian coastal dunes and its implications for nature management. Belg. J. Zool. 131 Suppl. 2: 111-118.

Dahl, E. 1998. The phytogeography of northern Europe (British isles, Fennoscandia and adjacent areas). Cambridge University Press, Cambridge, UK.

Depuydt, F. 1972. De Belgische strand en duinformaties in het kader van de geomorfologie der zuidoostelijke Noordzeekust. Verh. K. Acad. Wet. Lett. Schone Kunsten Belg. Kl. Wet. 34-122: 1-214.

De Raeve, F. 1989. Sand dune vegetation and management dynamics. In: van der Meulen, F., Jungerius P.D. \& Visser J.H. (eds.) Perspectives in coastal dune management, pp. 99-109. SPB Academic Publishing, Den Haag, NL.

Doing, H. 1993. Het Sileno-Tortuletum (ass. nov.), een karakteristieke associatie van het zeedorpenlandschap. Stratiotes 6: 40-52.

Droesen, W. 1998. Spatial modelling and monitoring of natural landscapes with cases in the Amsterdam Waterwork Dunes. Ponsen \& Looijen, Wageningen, NL.

Goldsmith, B. (ed.) 1991. Monitoring for conservation and ecology. Chapman and Hall, London, UK.

Herrier, J.-L.\& Killemaes, I. 1998. Acquisition and protection of the coastal dunes of Flanders. Coastline 4: 10-15.

Hoffmann, M., Cosyns, E., Deconinck, M., Lamoot, I. \& Zwaenepoel, A. 2001. Donkey diet in a Flemish coastal dune area in the first year after introduction. In: Houston, J.A., Edmondson, S.E. \& Rooney, P.J. (eds.) Coastal dune management, shared experience of European conservation practice, pp. 95-107. Liverpool University Press, Liverpool, UK.

Houston, J.A., Edmondson, S.E. \& Rooney, P.J. (eds.) 1998. Coastal dune management, shared experience of European conservation practice. Proceedings EUCC symposium, Southport, September 1998. Liverpool University Press, Liverpool, UK.

Jungerius, P.D. 1990. The characteristics of dune soils. In: Bakker, T.M.W., Jungerius, P.D. \& Klijn, J.A. (eds.) Dunes of the European coasts. Catena Suppl. 18: 155-162.

Kay, Q.O.N., Davies, E.W. \& Rich, T.C.G. 2001. Taxonomy of the western European endemic Asparagus prostratus (A. officinalis subsp. prostratus) (Asparagaceae). Bot. J. Linn. Soc. 137: 127-137.

Kooijman, A.M. \& Besse, M. 2001. The higher availability of $\mathrm{N}$ and $\mathrm{P}$ in lime-poor than in lime-rich coastal dunes in the Netherlands. J. Ecol. 90: 394-403.

Kooijman, A.M., Dopheide, J.C.R., Sevink, J., Takken, I. \& Verstraten, J.M. 1998. Nutrient limitations and their implications on the effects of atmospheric deposition in coastal dunes; lime-poor and lime-rich sites in the Netherlands. J. Ecol. 86: 511-526.

Lebrun, J., Noirfalise, P., Heinemann, P. \& Vanden berghen, C. 1949. Les associations végétales de Belgique. Bull. Soc. Roy. Bot. Belg. 82: 105-207.

Lichter, J. 2000. Colonisation constraints during primary succession on coastal Lake Michigan sand dunes. J. Ecol. 88: 825-839.

Lillesand, T.M. \& Kiefer, R.W. 2000. Remote sensing and image interpretation. 4th ed. John Wiley \& Sons, New York, NY, US.

Olff, H., Vera, F., Bokdam, J., Gleichman, J., De Maeyer, K. \& Smit, R. 1999. Shifting mosaics in grazed woodlands driven by the alternation of plant facilitation and competition. Plant Biol. 1: 127-137.

Provoost, S. 2004. Het kustecosysteem. In: Provoost, S. \& Bonte, D. (eds.) Levende duinen: een overzicht van de biodiversiteit aan de Vlaamse kust, pp. 10-45. Mededelingen van het Instituut voor Natuurbehoud 22, Brussel, BE.

Provoost, S. \& Hoffmann, M. (eds.) 1996. Ecosysteemvisie voor de Vlaamse kust. 2 Vols. Ghent University, Institute of Nature Conservation \& Ministry of the Flemish Community, Nature division. Brussels, BE.

Provoost, S. \& Van Landuyt, W. 2001. The flora of the Flemish coastal dunes (Belgium) in a changing landscape. In: Houston, J.A., Edmondson, S.E. \& Rooney, P.J. (eds.) Coastal dune management, shared experience of European conservation practice, pp. 393-401. Liverpool University Press, Liverpool, UK.

Reid, W.V. \& Miller, K.R. 1989. Keeping options alive: the scientific basis for conserving biodiversity. World Resources Institute, Washington DC, US.

Rodwell, J.S. 2000. British plant communities: maritime communities and vegetation of open habitats. Cambridge University, Cambridge, UK. 
Roisin, P. 1969. Le domaine phytogeographique atlantique d'Europe. Presses agronomiques Duculot, Gembloux, BE.

Rozema, J.P., Laan, P., Broeckman, R., Ernst, W.H.O. \& Appelo, C.A.J. 1985. On the lime transition and decalcification in the coastal dunes of the province of North Holland and the island of Schiermonnikoog. Acta Bot. Neerl. 34: 393-424.

Salisbury, E. 1952. Downs \& dunes: their plant life and its environment. Bell \& Sons, London, UK.

Slings, Q.L. 1994. De kalkgraslanden van de duinen. Levende Nat. 95(4): 120-130.

Tilman, D. 1985. The resource-ratio hypothesis of plant succession. Am. Nat. 125: 827-852.

van Breukelen, L., Cosyns, E. \& van Wieren, S. 2002. Wat weten we van terugdringen van duinstruwelen door herbivore zoogdieren? Levende Nat. 103(3): 101-105.

van Til, M., Ketner, P. \& Provoost, S. 2002. Duinstruwelen in opmars. Levende Nat. 103(3): 74-77.

Veer, M.A.C. 1997. Nitrogen availability in relation to vegetation changes resulting from grass encroachment in Dutch dry dunes. J. Coastal Conserv. 3: 41-48.

Veer, M.A.C. \& Kooijman, A.M. 1997. Effects of grassencroachment on vegetation and soil in Dutch dry dune grasslands. Plant Soil 192: 119-128.

Waumans, F. 2001. Vegetatie-ecologie van droge duingraslanden aan de Westkust. Thesis, Ghent University, Gent, BE.

Weeda, E.J. 1992. Zandviooltje (Viola rupestris) in de duinen van Noord-Kennemerland: hoe een dwerg uit de steppetoendra standhoudt temidden van zand, zeewind en konijnen. Wetenschappelijke mededelingen KNNV 206. KNNV Uitgeverij, Utrecht, NL.

Weeda, E.J., Doing, H. \& Schaminée, J.H.J. 1996. KoelerioCorynephoretea. In: Schaminée, J.H.J., Weeda, E.J. \& Westhoff, V. (red.) De vegetatie van Nederland 3. Graslanden-Zomen-Droge heiden, pp. 61-144. Opulus Press, Uppsala, SE \& Leiden, NL.

Weeda, E.J. \& Schaminee, J.H.J. 1990. Nomenclatorische en systematische notities met betrekking tot de KoelerioCorynephoretea. Stratiotes 13: 77-97.

Received 3 July 2003; Revision received 15 January 2004; Accepted 1 March 2004. Co-ordinating Editor: F. Taveira Pinto. 